\title{
GAJAH PURBA SEBAGAI IDE PENGEMBANGAN MOTIF BATIK SRAGEN
}

\section{Ancient Elephant as Development Idea of Sragen' Batik Motif}

\author{
Lili Hartono dan Mulyanto \\ Program Studi Pendidikan Seni Rupa FKIP UNS Surakarta, JI. Ir. Sutami 36 A Surakarta
}

\begin{tabular}{|c|c|c|}
\hline \multicolumn{3}{|c|}{ Korespondesi Penulis } \\
\hline Email & : liliart_ono@staff.uns.ac.id.dan mulyanto@staff.uns.ac.id & : 8 Januari 2020 \\
\hline & & : 14 Februari 2020 \\
\hline
\end{tabular}

Kata kunci: motif, batik, gajah, tulang

Keywords: motif, batik, elephant, bones

\section{ABSTRAK}

Kabupaten Sragen merupakan penghasil batik terbesar di wilayah eks Karesidenan Surakarta. Batik adalah salah satu produk unggulan Sragen, namun motif batik yang ada belum mencerminkan identitas daerah. Untuk itu, perlu dikembangkan motif batik yang mengambil ikon wilayah Sragen, yaitu situs Sangiran, khususnya bentuk gajah purba dan tulang. Tujuan penelitian ini adalah membuat motif batik yang memiliki karakteristik visual, sehingga dapat menjadi ikon daerah Sragen. Penelitian ini dilakukan di usaha kerajinan batik Jalidin, menggunakan metode kaji tindak partisipatif dan pengembangan kreativitas para pengrajin. Objek gajah dan tulang purba yang diteliti digunakan sebagai sumber ide dalam mengembangkan desain motif batik dengan mengembangkan kreativitas pengrajin. Hasil penelitian ada dua desain motif batik yang memiliki keunikan dan karakteristik wilayah Sragen, yaitu motif Rojo Gajah dan motif Balung Gajah. Kedua motif ini merupakan hasil eksplorasi dan pengembangan bentuk kepala gajah purba, gajah purba yang terdiri dari tulang, dan bentuk tulang bergaya. Bentuk desain motif meliputi satu motif desain untuk baju dan satu motif kain jarit yang juga bisa dibuat untuk pakaian. Penerapan pengembangan desain motif dilakukan dengan proses batik tulis dengan pewarna zat sintetis.

\section{ABSTRACT}

Sragen is the biggest batik producer in ex Residency of Surakarta. Batik is one of Sragen's main commodities; however its batik motifs have not reflected its regional identity. Therefore it is necessary to develop batik motifs using Sragen iconic symbol, Sangiran site, particularly ancient elephants and bones. The purpose of this study is to make batik motifs with visual characteristics so it can become Sragen's specialty. This research was carried out at Jalidin batik industry, using the participative action review method and the creativity development of the craftsmen. Ancient elephants and bones as the objects of the study were used as a source of ideas to develop batik motif designs by developing the creativity of the craftsmen. The results of the study are two batik motif designs that have uniqueness and characteristics, namely Rojo Gajah and Balung Gajah motif. Both of these motifs are the result of the exploration and development of the shape of an ancient elephant's head, ancient elephant consisting of bones, and stylized bone shapes. The motif designs consist of a design motif for clothing and a design motif for fabric which also can be made into clothing. The application of motif design onto the fabrics was carried out using hand-written batik process with synthetic color. 


\section{PENDAHULUAN}

Kabupaten Sragen merupakan salah satu kabupaten di Provinsi Jawa Tengah. Secara geografis Kabupaten Sragen berada di perbatasan antara Jawa Tengah dan Jawa Timur. Batas-batas wilayahnya, di sebelah timur, Kabupaten Sragen berbatasan langsung dengan Kabupaten Ngawi Provinsi Jawa Timur, sebelah barat Kabupaten Boyolali, sebelah selatan Kabupaten Karanganyar, dan sebelah utara Kabupaten Grobogan. Kabupaten Sragen termasuk salah satu kota kreatif penghasil produk batik yang menyerap tenaga kerja dalam jumlah besar, sudah berjalan sejak lama, dan memiliki kapasitas daya dorong, daya tarik, pendapatan dan sumbangan kesejahteraan yang berpotensi besar bagi masyarakat Sragen (Pratiwi, 2018). Potensi tersebut menjadikan batik menjadi subsektor unggulan ekonomi kreatif bagi Kabupaten Sragen.

Kabupaten Sragen memiliki beberapa produk unggulan seperti kerajinan mebel kayu jati, kerajinan wayang beber, kerajinan batu-batuan, beras organik, emping garut, dan kerajinan batik (Sragen, 2015). Usaha kerajinan batik pada tahun 2016 sebanyak 577 usaha dengan kapasitas produksi sebanyak 86.455 .000 potong batik dengan jumlah tenaga kerja yang diserap sebanyak 8.544 orang dan mayoritas adalah ibu rumah tangga yang juga berprofesi sebagai petani atau buruh tani (Sragen, 2015). Sentra kerajinan batik di Sragen terletak di enam desa, yaitu Desa Pilang, Kliwonan, Sidodadi, Gedongan, Jabung, dan Plupuh. Kabupaten Sragen melalui Dinas Perindustrian, Koperasi dan UMKM, berkaitan dengan program ini antara lain sebagai berikut: (1) mengembangkan industri unggulan yang ada di Kabupaten Sragen, termasuk usaha kerajinan batik, (2) meningkatkan efisiensi dan efektivitas proses produksi batik, (3) mengembangkan dan memperluas jejaring UKM batik, baik dengan UKM yang ada di wilayah Kabupaten Sragen maupun dengan UKM dari daerah lain, (4) mengembangkan skema permodalan yang sesuai dengan UKM batik, (5) mengembangkan manajemen pemasaran produk batik, dan (6) meningkatkan pendapatan karyawan UKM batik (Sragen, 2015).

Desa Pilang merupakan daerah yang menjadi sentra kerajinan batik di Kabupaten Sragen, di desa Pilang ini terdapat 32 pengusaha batik yang meliputi usaha di bidang kerajinan batik dengan berbagai teknik, seperti batik tulis, batik cap, dan batik kombinasi cap dan tulis. Usaha batik yang menjadi mitra kegiatan penelitian ini adalah usaha kerajinan batik Jalidin.

Usaha batik Jalidin beralamat di Desa Pilang, Kecamatan Masaran, Sragen. Usaha kerajinan batik Jalidin, memproduksi batik tulis, batik cap, dan batik kombinasi. Selain itu usaha batik Jalidin juga menerima jasa pembuatan desain motif dan pewarnaan batik.

Dilihat dari aspek motif yang dihasilkan, produk yang dihasilkan oleh batik Jalidin sudah sangat baik dengan ragam bentuk motif yang cukup banyak dan bervariasi, namun masih ada permasalahan yang dihadapi, yaitu masih kurang mampu menerjemahkan konsep desain menjadi visual motif yang baik, karena selama ini memiliki kecenderungan membuat produk dari mencontoh produk yang sudah ada atau hanya menuruti permintaan konsumen. 
Produk batik yang dibuat pada umumnya dalam komposisi yang simetris sehingga tampak monoton dan kurang dinamis. Produk batik yang dihasilkan usaha kerajinan batik Jalidin mayoritas berupa jarik dan batik pola baju atau hem. Usaha kerajinan batik Jalidin belum mampu melakukan pengembangan desain motif batik yang multifungsi, artinya motif yang bisa digunakan untuk jarik sekaligus bisa digunakan untuk membuat baju lengan panjang maupun lengan pendek ketika telah dijahit, motifnya sanggit atau motifnya menyambung utuh. Karena itu, diperlukan pendampingan terhadap usaha batik Jalidin dalam pengembangan desain motif batik yang multifungsi, bisa dipergunakan untuk jarik sekaligus hem.

Penggalian potensi suatu daerah sebagai sumber ide penciptaan desain motif agar bisa menjadi batik khas daerah tertentu telah banyak dilakukan. Seperti di Ponorogo, Kupang, dan Bali. Ponogoro memiliki kesenian khas yang telah dikenal di seluruh masyarakat Indonesia berupa kesenian "reog". Di dalam kesenian reog memiliki banyak unsur pendukung yang dapat dikembangkan menjadi motif batik (Mulyanto \& Hartono, 2018). Sementara itu sebagai daerah tujuan wisata yang telah dikenal hingga luar negeri, Bali memiliki banyak sekali tempat wisata yang menarik untuk dikunjungi, seperti Pantai Kuta, Pura Tanah Lot, Garuda Wisnu Kencana, Danau Beratan Bedugul, Kintamani, dan lain sebagainya. Tempat-tempat wisata tersebut telah dijadikan dasar dalam pengembangan desain motif batik khas Bali yang memiliki bentuk unik dan karakteristik (Irfa'ina Rohana S, Masiswo, Yudi Satria, 2015).
Sedangkan di Kupang, Nusa Tenggara Timur memiliki tenun ikat daerah yang unik, indah, dan mengandung nilai filosofis. Motif tenun ikat tradisional mempunyai ciri khas motif dengan pola geometris, karena pada dasarnya teknis tenun adalah penganyaman benang lusi dan pakan pola geometris adalah desain motif dengan pola yang terukur, berulang dan teratur. Aneka ragam hias motif tenun ikat Kupang merupakan kekayaan budaya yang berharga, yang telah dijadikan sumber inspirasi penciptaan motif batik baru yang mempunyai kekhasan daerah Kupang (Salma et al., 2016). Menyebut nama Jepara maka orang akan langsung teringat seni ukir kayunya yang indah pada berbagai perabot mebel, arsitektur, dan aneka produk aksesoris interior lainnya. Jepara memang termasyhur karena kepandaian seni ukir. Ornamen ukir corak Jepara berupa tumbuhan-tumbuhan yang dirangkai dengan motif hewan. Bentuknya menjalar yang berbatang dan beranting halus ramping. Gerak tumbuhnya melingkar-lingkar secara gemulai. Batang beruas yang ditumbuhi trubusan atau tangkai bergelung yang berakhir dengan bunga atau daun. Daunnya tergolong jenis bertulang jari dengan pecahan pada setiap jarinya dan masing-masing berujung runcing dan sebagian juga berbentuk ulir. Secara keseluruhan ornamen bercorak motif ukir Jepara tampak ramping, ringan dan lemah gemulai. Motif ukir tradisional Jepara merupakan stilasi atau penggayaan dari bentuk tumbuhan menjalar. Bersumber dari motif ukir ini telah dijadikan sumber ide pengembangan motif batik khas Jepara (Wulandari \& Salma, 2019). 
Daerah Kabupaten Sragen memiliki Wilayah Sangiran di kaki Gunung Lawu dan lembah Bengawan Solo yang merupakan situs arkeologi manusia berdiri tegak terlengkap di Asia (Nurwanti, 2013). Daerah yang berlokasi di utara Kabupaten Surakarta ini menghadirkan informasi lengkap tentang sejarah kehidupan manusia purba. Di sini tersedia berbagai informasi tentang habitat, pola kehidupan, binatang yang hidup bersama manusia pada zaman itu, hingga proses terjadinya bentang alam dalam kurun waktu tidak kurang dari 2 (dua) juta tahun lampau (Ernifiaty, 2012). Museum ini memiliki banyak koleksi fosil manusia purba. Ada juga fosil hewan bertulang belakang, fosil binatang air, batuan, fosil tumbuhan laut, alat-alat batu, dan beberapa jenis hewan seperti badak, sapi, rusa, banteng, dan kerbau. Sejak tahun 1977 situs Sangiran ditetapkan oleh Menteri Pendidikan dan Kebudayaan Indonesia sebagai cagar budaya. Tahun 1996 Sangiran terdaftar dalam Situs Warisan Dunia UNESCO sebagai World Heritage (No. 593, dokumen WHC96/Conf.201/21).

Gajah purbakala merupakan bentuk yang sangat erat dengan situs purbakala Sangiran. Hal ini dikarenakan pada situs ini banyak ditemukan fosil gajah purbakala. Dari identifikasi yang dilakukan menunjukkan bahwa di Sangiran pernah menjadi hunian tiga generasi gajah purba yaitu: (1) Mastodon adalah jenis gajah paling primitif di Sangiran memiliki empat gading, dua berukuran besar tumbuh di rahang atas, dan dua lainnya berukuran mungil di rahang bawah, (2) Stegodon yang banyak ditemukan di Sangiran berjenis Stegodon trigonocephalus. Ukuran tubuhnya lebih besar dibandingkan gajah sekarang. Dia memiliki gading berbentuk bulat dan agak melengkung, (3) Elephas merupakan jenis gajah yang paling modern. Bentuknya relatif sama dengan gajah sekarang.

Pengembangan desain motif batik dengan bentuk gajah dan tulang purba sebagai sumber ide penciptaannya dilakukan sebagaimana pengembangan desain pada umumnya, yaitu tetap mempertimbangkan prinsip-prinsip desain. Prinsip desain juga merupakan bagian estetis bagi suatu karya seni diantaranya adalah irama atau keselarasan, kesatuan, dominasi, keseimbangan, proporsi atau keserasian, kesederhanaan dan kejelasan (Sanyoto, 2009). Suatu karya seni yang memiliki keindahan, berarti telah memenuhi prinsip dasar penciptaan karya seni. Ketujuh prinsip dasar tersebut yaitu: (1) irama atau keselarasan bentuk, (2) kesatuan (saling berhubungan antara unsur satu dengan yang lainnya), (3) dominasi dapat disebut juga dengan pusat perhatian, keseimbangan antara bentuk satu dengan yang lainnya, (5) proporsi atau keseimbangan antara bentuk satu ke bentuk yang lainnya, (6) kesederhanaan (tidak lebih dan tidak kurang), (7) kejelasan sehingga mudah dipahami.

Hal pertama yang dilakukan dalam menciptakan sebuah karya seni adalah merumuskan latar belakang penciptaan yang diperoleh dari pengalaman empiri, pengamatan lapangan, kemudian data-data tersebut diolah sehingga menghasilkan ide penciptaan yang didasari dengan alasan, tujuan dan manfaat penciptaan yang terumuskan dalam latar belakang 
IKh Dinamika Kerajinan dan Batik: Majalah Ilmiah. Vol. 37 No. 1, Juni 2020, Hal. 1 - 14

penciptaan. Setelah latar belakang penciptaan didapat kemudian muncul rumusan masalah penciptaan yaitu bagaimana mewujudkan ide menjadi karya. Setelah itu, menentukan pendekatan teoretis yang akan digunakan. Berpijak pada rumusan masalah penciptaan dan pendekatan teoretis yang dipilih, maka dapat dirumuskan konsep penciptaan. Konsep penciptaan yang dirumuskan meliputi konsep isi dan konsep bentuk yakni visual karya yang akan dibuat. Dalam merumuskan konsep bentuk karya, haruslah mempertimbangkan kajian data acuan. Setelah itu didapatlah rancangan bentuk karya yang berwujud sketsa (Gustami, 2008). Setelah semua konsep isi dan bentuk, tahap terakhir dalam penciptaan karya seni adalah proses perwujudan, yaitu mewujudkan konsep yang dituangkan ke dalam aspek visual karya. Visual karya disusun berdasarkan teori estetika yaitu dengan menggunakan prinsip-prinsip dasar seni rupa.

Pengembangan desain motif batik dilakukan secara sinergis kepada semua pihak yang terkait, mulai dari pengusaha batik, pendesain/desainer, tukang batik, dan tukang warna. Pelaksanaan kegiatan dilakukan berdasarkan tujuan dari setiap tahapan proses. Hal ini dilakukan agar setiap tahapan proses dapat berjalan secara berkesinambungan.

Berdasarkan permasalahan bahwa batik Jalidin masih mengalami kesulitan dalam menerjemahkan konsep menjadi desain motif, maka penulis mengajak batik Jalidin melakukan pengembangan desain motif batik dengan mengangkat konsep gajah purba sebagai ikon daerah Sragen. Tujuan penelitian ini adalah untuk mengembangkan desain motif batik dengan menjadikan gajah purba sebagai konsep penciptaan sehingga dihasilkan batik khas daerah Sragen.

\section{METODOLOGI PENELITIAN}

Metode pengumpulan data yang digunakan dalam penelitian ini adalah kajian pustaka, wawancara, observasi, dan dokumentasi. Kajian pustaka dilakukan sebagai langkah awal untuk mengidentifikasi dan menganalisis hal yang terkait situs Purbakala Sangiran yang akan dijadikan sumber ide pengembangan desain motif batik. Dari kajian pustaka ditentukan dari situs Sangiran yang dianggap mewakili adalah bentuk gajah purba. Observasi dan dokumentasi digunakan untuk mengamati langsung ke situs Sangiran agar mendapat secara langsung bentuk gajah purba yang akan dikembangkan. Selain itu dilakukan juga pengamatan terhadap produk batik yang saat ini ada di pasaran, untuk memperoleh desain motif, warna, dan produk yang diminati konsumen. Metode pendekatan yang digunakan dalam penelitian ini adalah pendekatan kaji tindak partisipatif individual dan metode pengembangan kreativitas (Kaufman \& Sternberg, 2007). Pelaksanaan kegiatan pengembangan desain motif batik, mulai dari proses pemilihan sumber ide penciptaan hingga proses perwujudan dilakukan dengan melibatkan semua unsur terkait, mulai dari pemilik usaha, pendesain/desainer, pembatik (tukang canting), dan tukang warna dilibatkan secara aktif dalam setiap proses. Pada setiap proses terjadi diskusi aktif dengan peneliti dan pihak terkait, sehingga diharapkan mereka 
dapat memahami permasalahan yang dihadapi dalam pengembangan desain motif baru pada tiap proses dan mampu mencari solusi terbaik dari permasalahannya.

Bahan dan alat yang digunakan dalam penelitian ini dapat dibagi menjadi dua, yaitu bahan dan alat yang digunakan pada tahap pembuatan desain motif batik dan yang digunakan pada proses perwujudan batik. Bahan dan alat yang digunakan pada tahap pembuatan desain motif adalah kertas gambar ukuran A0, kertas kalkir, pensil 2B, karet penghapus, spidol kecil, penggaris, komputer, printer, dan flashdisk. Bahan untuk proses perwujudan batik adalah kain katun primissima, malam, dan pewarna sintetis napthol untuk warna hitam dan merah serta indigosol untuk warna hijau dan kuning. Sedangkan alat yang digunakan yaitu canting tulis, kompor batik, wajan batik, gawangan, bak pewarna, dan bak lorod.

Tahap pertama yang dilakukan adalah melakukan kajian terkait objek yang akan diangkat menjadi ikon daerah Sragen melalui sumber data berupa pustaka, tokoh masyarakat, budayawan, pendesain motif, dan pecinta batik dengan menggunakan teknik, wawancara, observasi, dan kajian pustaka. Hasil dari kegiatan ini, objek yang akan diangkat adalah binatang gajah purba dan tulang purba. Selanjutnya proses visualisasi, dengan membuat sketsa alternatif dengan mengangkat tema objek gajah purba dan tulang berdasarkan kajian terhadap referensi yang didapatkan disertai imajinasi. Imajinasi membantu menemukan inovasi atau kebaruan dalam kreativitas penciptaan seni (Eskak, 2013). Setiap hasil desain motif batik yang telah dibuat selanjutnya dibahas bersama dengan narasumber untuk mendapatkan desain terbaik yang kemudian dibuat menjadi desain motif dengan skala ukuran 1:1 di atas kertas A0 dan kemudian dipindah ke kertas kalkir. Tahap selanjutnya adalah memindah desain motif yang telah dibuat di atas kertas ke kain katun. Selanjutnya dilakukan proses perwujudan desain motif menjadi karya kriya batik melalui pendekatan aktif dan partisipatif pada setiap tahap perwujudannya, mulai dari nyorek, nyanting, memberi isen-isen, mewarnai, hingga pelorodan.

\section{HASIL DAN PEMBAHASAN}

Tahapan dan proses pengembangan desain motif batik secara umum yaitu: melakukan analisis pasar, penyusunan konsep desain, dan pengembangan desain motif batik (Mulyanto \& Hartono, 2018). Dari proses tersebut telah ditentukan bahwa yang akan menjadi objek utama dalam pengembangan desain batik berdasarkan analisis adalah situs purbakala Sangiran yang berada di Kabupaten Sragen dan sudah menjadi salah satu tempat wisata unggulan daerah, bahkan sudah terbentuk pendapat masyarakat umum bahwa tidak ada Sangiran, berarti tidak ada Sragen. Dari Situs Purbakala Sangiran, bentuk utama yang akan dijadikan sumber ide penciptaan dalam pengembangan desain motif batik adalah gajah purba dan tulang purba. Gajah purba, khususnya bentuk gading purba merupakan ikon yang saat ini sedang giat dibangun dan dikembangkan oleh pemerintah daerah Kabupaten Sragen. Beberapa tempat strategis di Kabupaten Sragen, seperti gapura perbatasan antara kabupaten Sragen dengan Kabupaten 

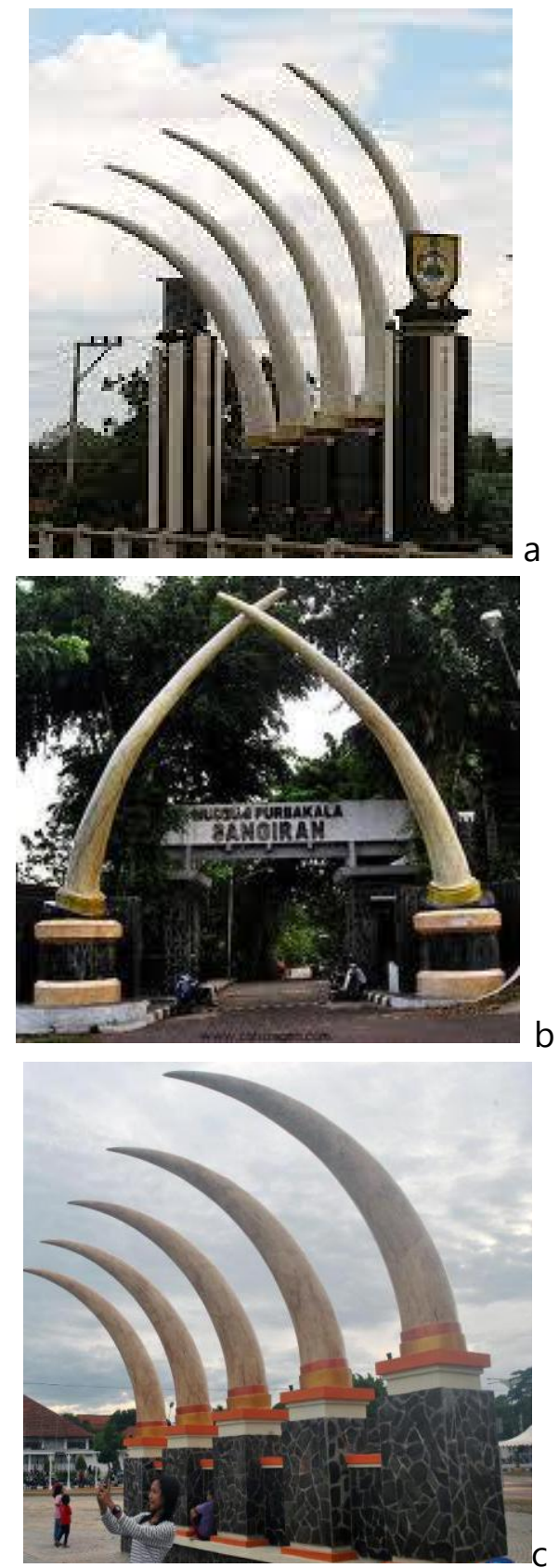

Gambar 1. a. Tugu gading gajah sebagai pintu masuk Kabupaten Sragen dari arah Solo; b. Tugu gading gajah purba yang berdiri di pintu masuk

Museum Manusia Purba Sangiran; c. Tugu gading gajah purba yang berdiri di kawasan Air

Mancur Alun-alun Sasana Langen Putra

Karanganyar, gapura di situs Sangiran, tugu perbatasan Jawa Tengah dengan Jawa Timur di Desa Banaran, Sambungmacan, dan tugu gading di alun-alun Sragen dapat dilihat pada Gambar 1.
Produk yang dibuat ada dua jenis, yaitu desain motif pola batik yang digunakan untuk baju (hem) lengan pendek dengan hasil jahitannya motif sanggit dan kain jarik yang juga bisa dibuat menjadi baju lengan panjang/pendek dengan hasil jahitan yang motifnya sanggit. Pengembangan motif dilakukan mengacu pada makna simbolis yang terkandung didalamnya, sesuai dengan karakteristik budaya masyarakat setempat (Djumena, 1990); Santoso, 2002); Hamzuri, 1981). Agar desain motif batik yang dihasilkan memiliki kualitas baik, maka pelaksanaannya melalui berbagai pertimbangan, seperti aspek estetika, fungsi, nilai ekonomis, ergonomis, kualitas, aspek sosial budaya, dan aspek lingkungan (Prasetyowibowo, 1998). Pengembangan desain batik tidak bisa lepas dari unsurunsur keindahan visual (Masiswo \& Atika, 2014). Adapun proses dan tahapan pengembangan desain motif batik khas daerah Sragen dilakukan melalui beberapa langkah, yaitu: (1) mengidentifikasi dan mengkaji berbagai unsur-unsur visual yang terdapat dan ditemukan pada situs purbakala Sangiran; (2) memilih unsur-unsur visual pada situs purbakala Sangiran yang dianggap dominan, bisa menjadi representasi, dan menjadi ikon daerah Kabupaten Sragen dengan mempertimbangkan unsur-unsur seni rupa yang relevan; dan (3) menyusun unsur-unsur visual yang dipilih dan ditetapkan berdasarkan atas prinsip-prinsip desain (Mulyanto \& Hartono, 2018).

Desain motif batik yang telah diciptakan dalam penelitian ini sebanyak dua buah, yaitu motif Rojo Gajah dan motif Balung Gajah. Kedua motif ini sama-sama menjadikan bentuk gajah purba dan tulang 
purba sebagai sumber ide dalam penciptaannya. Walaupun ada perbedaan pada aspek penentuan point of interest. Pada motif Rojo Gajah yang menjadi motif pokok adalah bentuk kepala gajah tampak dari dari depan, sedangkan pada motif Balung Gajah, yang menjadi motif pokok adalah bentuk gajah yang berupa tulang belulang.

\section{Motif Rojo Gajah}

Motif ini menjadikan bagian kepala gajah purbakala sebagai sumber ide pokok dalam pengembangan desain motif batik yang didukung dengan unsur bentuk tulang kaki binatang purba seperti pada Gambar 2b dan 2c. Bentuk kepala gajah purba ditampilkan frontal tampak dari depan dengan belalai yang menjulur ke depan. Gajah purbakala dipilih menjadi motif pokok karena merupakan bentuk yang sangat erat dengan situs purbakala Sangiran, bisa menjadi representasi, dan dominan sehingga tepat bila dikembangkan menjadi desain motif batik khas daerah Sragen.

Identifikasi temuan berbagai fosil purba menunjukkan bahwa di Sangiran pernah menjadi hunian gajah purba dari jenis
Mastodon, Stegodon, dan Elephas. Ciri fisik yang membedakan dari ketiga gajah tersebut adalah pada tipe gigi dan bentuk gadingnya. (1) Gajah purba jenis Mastodon memiliki empat gading, dua berukuran besar tumbuh di rahang atas, dan dua lainnya berukuran mungil di rahang bawah.

Gigi geraham Mastodon bertipe bunodon. (2) Gajah purba jenis Stegodon berjenis Stegodon trigonocephalus. Spesies yang beratap tengkorak menonjol membentuk segitiga. Memiliki gading berbentuk membulat dan agak melengkung. Gigi Stegodon bertipe brachyodont yaitu jenis gigi yang sesuai untuk melumat dedaunan yang lembut. (3) Gajah purba jenis Elephas, merupakan generasi ketiga gajah purba. Bentuk gading Elephas relatif lurus. Gigi Elephas bertipe hipsodon yang digunakan untuk mengunyah makanan yang keras seperti rumput kering dan bijibijian (BPSMP Sangiran, 2017)

Gading gajah dibuat agak besar dan melengkung. Untuk mendukung kepala gajah sebagai point of interest, dibuat motif parang yang merupakan stilasi dari bentuk tulang purba dengan membentuk pola $\mathrm{V}$ seperti tampak pada Gambar 2c.
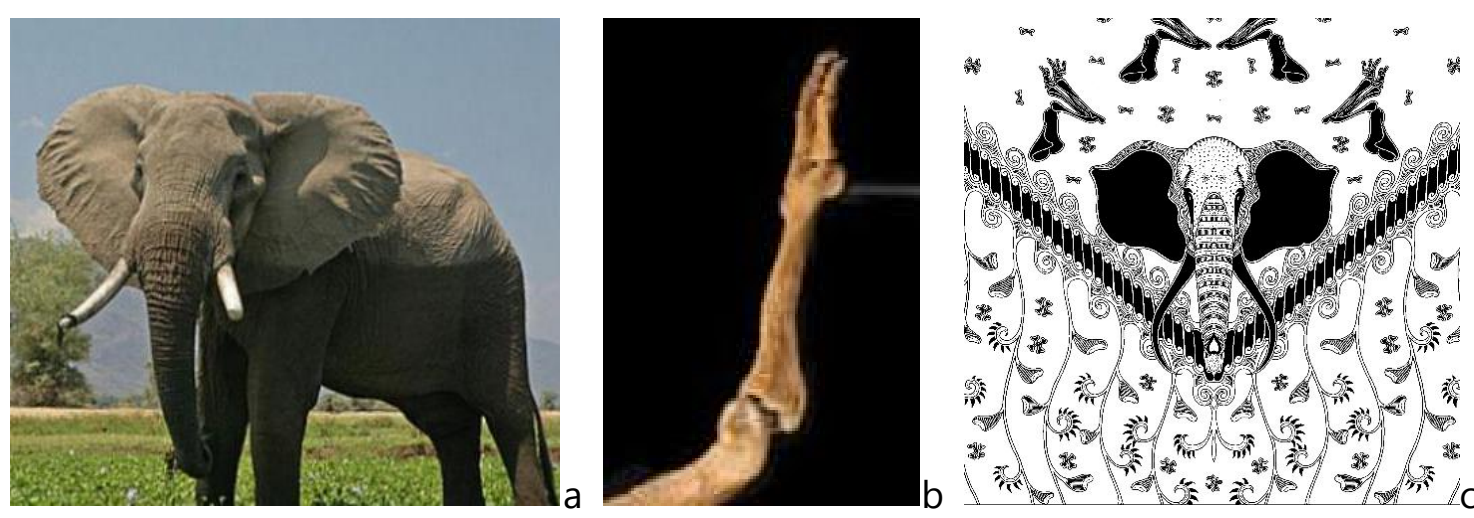

Gambar 2. a. Gambar gajah purba; b. Gambar tulang purba; c. Pengembangan desain motif batik dengan sumber ide gajah purba dan tulang purba 

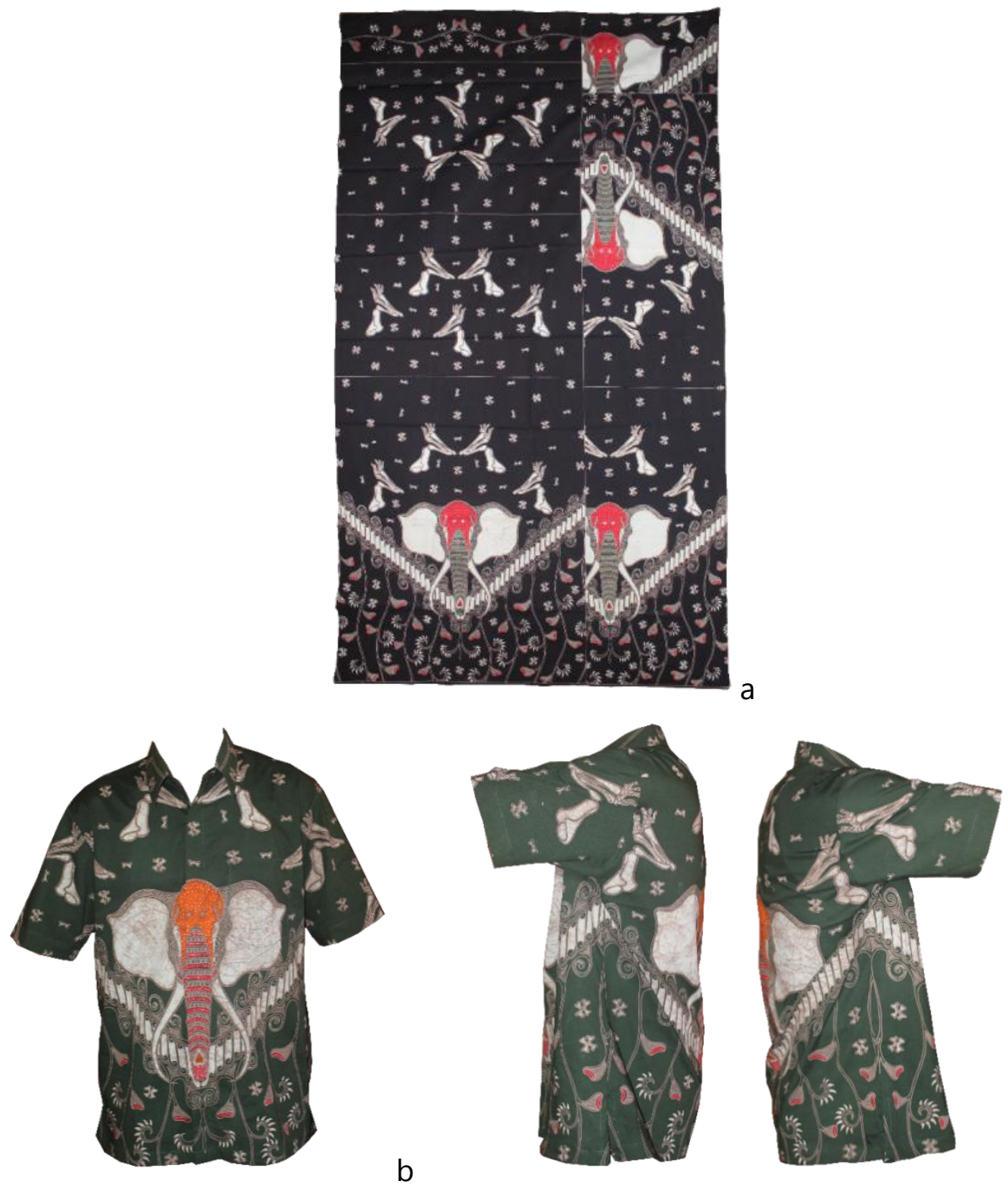

C

Gambar 3. a. Hasil pengembangan desain motif batik yang berupa kain batik pola baju lengan pendek; b. Kemeja lengan pendek, motif bagian depan sangit tampak depan; c. Kemeja lengan pendek, motif bagian samping kiri dan kanan sanggit

Pada bagian bawah desain motif sumber ide penciptaan Sangiran sebagai dikombinasikan dengan unsur motif lunglungan tumbuh-tumbuhan merambat, situs purbakala, pada bagian atas diberi dengan variasi bentuk daun dan bunga. aksentuasi tulang kaki dan telapak kaki Bentuk motif daun dan bunga mengambil binatang purba yang didukung dengan bentuk tulang purba yang di stilasi atau motif stilasi tulang dengan ukuran yang digayakan. Hal ini dilakukan agar desain lebih kecil yang disusun menyebar secara motif yang dihasilkan tampak luwes, acak pada bagian-bagian bidang kosong, menarik, dan dinamis. Untuk mendukung namun tidak terlalu rapat dan banyak, sehingga komposisi motif tidak terlalu 
padat. Motif lung-lungan dari stilasi tumbuh-tumbuhan merambat diterapkan untuk memperkuat sumber ide penciptaan, yaitu mencerminkan dan menampakkan suasana kehidupan pada jaman purba dulu yang masih banyak tumbuh-tumbuhan. Motif tersebut kemudian diperkuat dengan pewarnaan menggunakan warna dominan hijau pada bagian background, dengan kombinasi warna putih, kuning, dan merah pada bagian-bagian tertentu sebagai aksentuasi agar tidak monoton. Pewarna yang digunakan pada batik ini menggunakan pewarna sintetis. Hasil kain batik yang dihasilkan merupakan batik pola, sehingga saat dibuat menjadi hem, motif bagian kepala gajah purba pada bagian sambungan depan sanggit dan menyambung seperti tampak pada Gambar 3b, dan motif parang pada bagian sambungan samping kanan-kiri juga sanggit seperti pada Gambar 3c.

\section{Motif Balung Gajah}

Motif batik ini merupakan pengembangan dan eksplorasi visual yang bersumber dari bentuk gajah purba yang ditampilkan secara lengkap dan utuh. Namun visualisasinya hanya berupa tulangbelulang yang diselingi dengan stilasi dari bentuk tulang dengan persendiannya seperti tampak pada gambar 2c. Bentuk tulang gajah dibuat secara utuh lengkap dengan gading yang besar, bentuknya membulat dan melengkung. Bentuk gading gajah dibuat tampak lebih besar, melengkung, dan panjang, agar secara mudah terlihat beda dengan bentuk gading gajah sekarang. Seperti desain motif yang pertama, desain motif kedua juga tetap memilih gajah purba yang dijadikan ikon Kabupaten Sragen. Binatang gajah purbakala ditampilkan dalam bentuk tulang-belulang untuk memperkuat visualisasi tentang situs purbakala Sangiran. Persepsi masyarakat pada umumnya saat mendengar kata situs purbakala tentunya akan membayangkan tulang-tulang manusia dan binatang purba. Sehingga diharapkan desain motif batik yang dihasilkan bisa memiliki kekhasan daerah Kabupaten Sragen yang identik dengan situs purbakala Sangiran.

Pengembangan desain motif batik dibuat dengan komposisi motif yang asimetris, Bentuk tulang gajah ditampilkan secara utuh dengan gading yang besar agar memperkuat citra binatang purba. Motif gajah purba disusun selang-seling mengikuti garis diagonal motif parang. Setiap garis diisi tiga buah motif gajah yang disusun berulang ke samping kanan dan kiri, sehingga motif gajah purba dapat ditarik garis lurus vertikal dan horizontal. Untuk mendukung komposisi motif, dibuat latar motif bunga yang merupakan bentuk stilasi dari bentuk tulang purba yang diselingi dengan motif tulang ekor yang terkesan seperti bentuk gading purba seperti tampak pada gambar 4e. Untuk memperkuat kesan dan suasana purba, maka pada batik ini menggunakan warna hitam sebagai warna yang paling dominan yang diselingi warna merah, menggunakan pewarna sintetis. Hasil batik yang diperoleh berupa kain jarik, saat dijahit menjadi hem lengan panjang maupun pendek pada sambungan depan bisa sanggit seperti pada gambar 5b. 

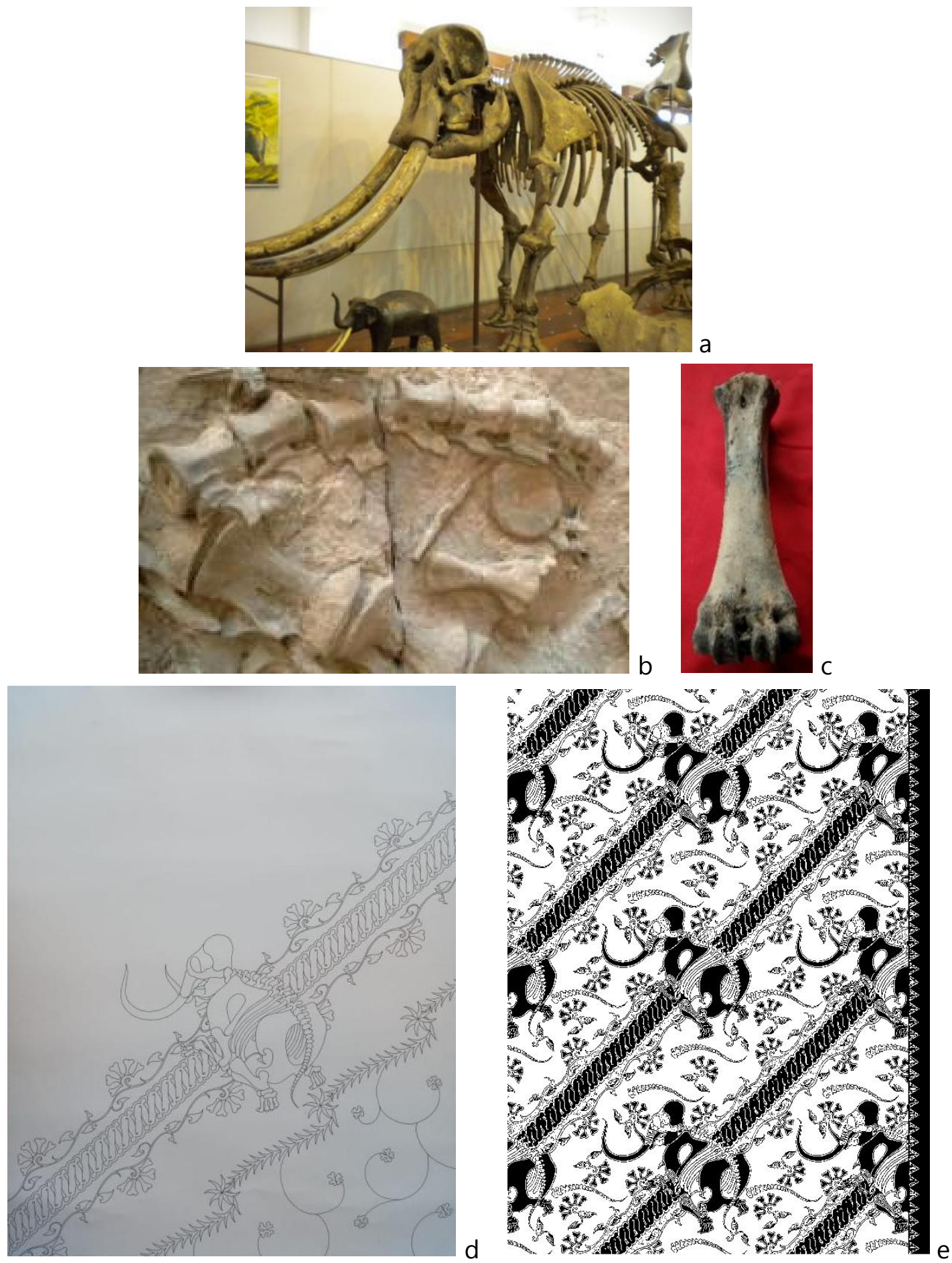

Gambar 4. a. Kerangka binatang gajah purba yang disusun secara utuh; b. Tulang belakang binatang purba; c. Tulang kaki binatang purba; $d$. Alternatif motif hasil pengembangan yang bersumber dari bentuk tulang gajah purba; e. Desain motif hasil pengembangan yang bersumber dari bentuk tulang gajah purba 
IlKh Dinamika Kerajinan dan Batik: Majalah Ilmiah. Vol. 36 No. 1, Juni 2019, Hal. 1- 14
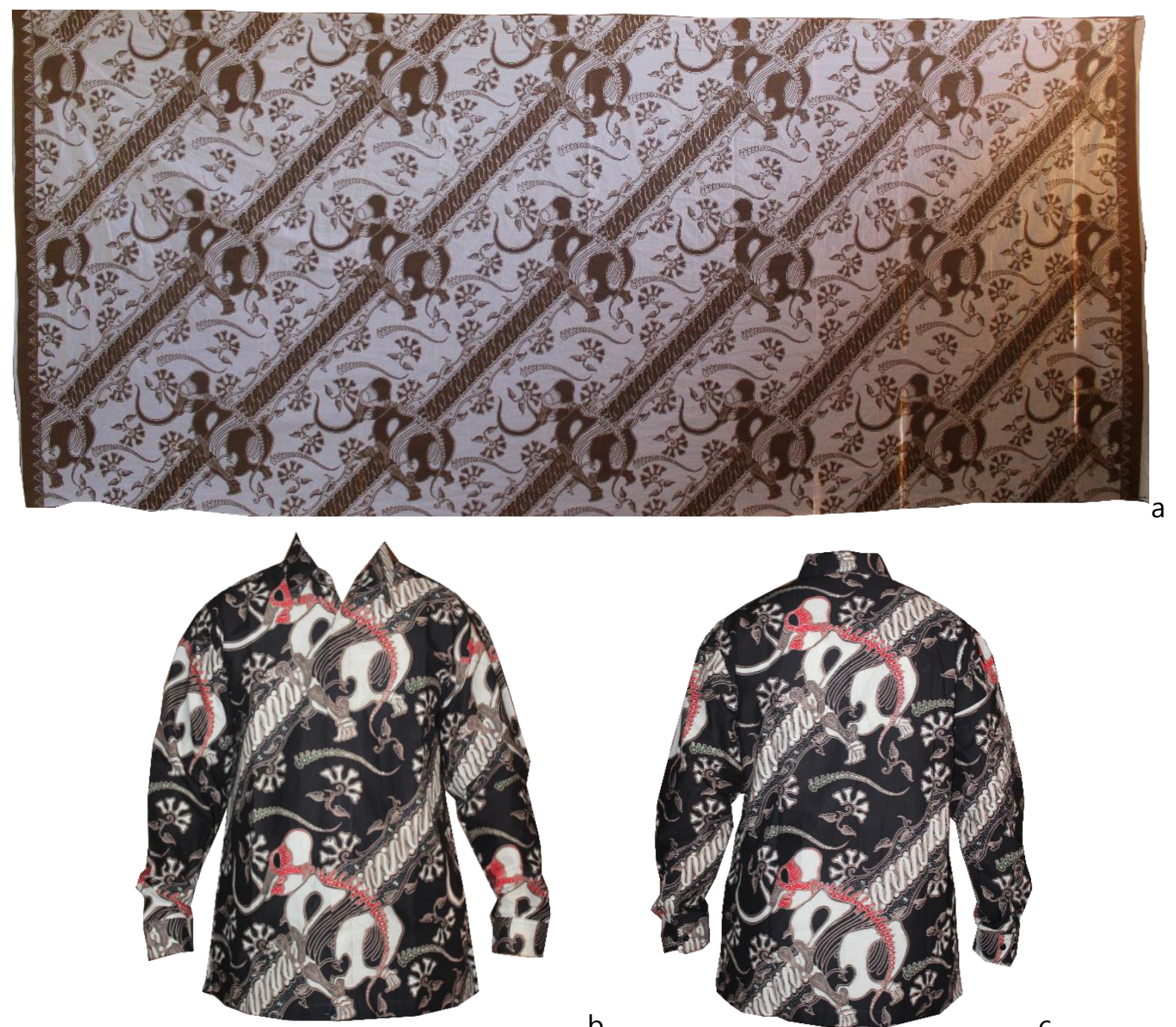

b

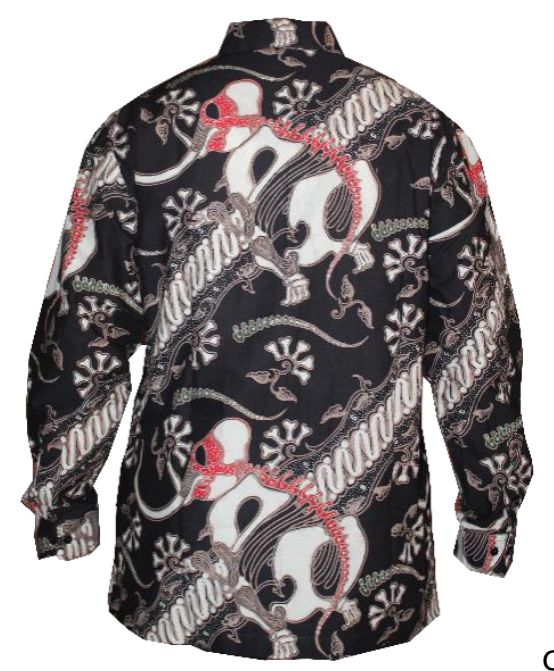

Gambar 5. a. Hasil pengembangan desain motif yang berupa kain jarik yang dapat dibuat hem lengan panjang; b. Kemeja lengan panjang, motif bagian depan sangit; c. Kemeja lengan panjang tampak belakang

\section{KESIMPULAN DAN SARAN}

Situs purbakala Sangiran, khususnya gajah purba dan tulang telah berhasil dijadikan sumber ide penciptaan desain motif batik baru yang menjadi produk khas Kabupaten Sragen. Hasil dari penelitian ini berupa dua buah desain motif batik yang unik dan menarik, yaitu: motif batik Rojo Gajah dan Balung Gajah. Desain motif yang dihasilkan untuk produk batik Rojo Gajah berupa kain batik pola yang digunakan untuk kemeja lengan pendek, sedangkan batik Balung Gajah berupa kain jarik yang juga dapat dibuat menjadi baju lengan panjang/pendek tapi hasil jahitannya motif tetap sanggit.

Berdasarkan hasil penelitian yang telah dilakukan, dapat dilihat bahwa perajin 
Jalidin telah mampu mengembangkan desain motif yang baru dengan mengambil konsep penciptaan dari bentuk gajah dan tulang purba sebagai ikon daerah Kabupaten Sragen. Hal ini secara tidak langsung bertujuan untuk memajukan daerah setempat. Agar desain motif batik yang dihasilkan dapat dikenal masyarakat lebih luas, perlu dilakukan sosialisasi yang lebih luas dan aktif mengikuti kegiatan pameran.

\section{KONTRIBUSI PENULIS}

Penulis adalah penulis utama dan sekaligus merupakan kontributor utama dalam penulisan artikel dengan judul Gajah Purba sebagai Ide Pengembangan Motif Batik Sragen ini

\section{UCAPAN TERIMA KASIH}

Terimakasih yang sebesar-besarnya diucapkan kepada usaha kerajinan Batik Jalidin Sragen yang telah bekerjasama dengan baik dan berperan secara aktif dalam penelitian ini, sehingga diperoleh hasil sesuai yang diharapkan.

\section{DAFTAR PUSTAKA}

BPSMP Sangiran. (2017). Tiga Generasi Gajah di Sangiran.

https://kebudayaan.kemdikbud.go.id/bpsm psangiran/tiga-generasi-gajah-disangiran/

Djumena, N. S. (1990). Batik dan Mitra. Djambatan.

Ernifiaty, E. (2012). Perkembangan Museum Situs Sangiran dan Pengaruhnya Terhadap Ilmu Pengetahuan Tahun 1974-2004. Journal of Indonesian History, 118-124.

Eskak, E. (2013). Rupa Karsa: Eksplorasi Limbah dalam Seni. Institut Seni Indonesia Yogyakarta.
Gustami, S. (2008). Uji Teori Trilogi Keseimbangan dengan Metode Tiga Tahap-Enam Langkah Penciptaan Seni Kriya di Kalangan Mahasiswa. Jurusan Kriya, Fakultas Seni Rupa, Institut Seni Indonesia.

Hamzuri. (1981). Batik Klasik. Jakarta: Djambatan.

Salma, I.R., Masiswo, \& Satria, Y, A. A. W. (2015). Pengembangan Motif batik Khas Bali. Dinamika Kerajinan Dan Batik, 32 (1), 23-34.

Kaufman, J. C. \& Sternberg, R. J.. (2007). Creativity. Journal of Change, 39(4).

Masiswo \& Atika, V. (2014). Aplikasi Ornamen Khas Maluku untuk Pengembangan Desain Motif Batik. Dinamika Kerajinan Dan Batik, 31 (1), 21-30.

Mulyanto, \& Hartono, L. (2018). Kesenian Reog Sebagai Sumber Ide Pengembangan Desain Motif Batik Ponorogo. Dinamika Kerajinan Dan Batik: Majalah Ilmiah. 35 (1), 33-44.

Nurwanti, Y. H. E. S. I. H. S. (2013). Kajian Sosial, Budaya, dan Ekonomi Masyarakat di Kawasan Situs Sangiran. Yogyakarta: Balai Pelestarian Nilai Budaya (BPNB).

Prasetyowibowo, B. (1998). Desain Produk Industri. Bandung: Yayasan Delapan Sepuluh

Pratiwi, R. D. (2018). Profil Kota/Kabupaten Kreatif - Kabupaten Sragen. https://indiekraf.com/profilkabupatensrage $\mathrm{n} /$

Salma, I. R., Eskak, E., \& Nugroho, A. A. (2016). Kreasi Batik Kupang. Dinamika Kerajinan Dan Batik. 33 (1), 45-54. https://doi.org/10.22322/dkb.v33i1.1040

Santoso, D. (2002). Batik: Pengaruh Zaman dan Lingkungan. Surakarta: PT Batik Danarhadi.

Sanyoto, S. E. (2009). Nirmana Elemen-Elemen Seni Dan Desain. Yogyakarta: Jalasutra.

Sragen, P. D. K. (2015). Sragen dalam Angka.

Wulandari, E. A., \& Salma, I. R. (2019). Motif Ukir dalam Kreasi Batik Khas Jepara. Dinamika Kerajinan Dan Batik. 36 (1), 17-34. https://doi.org/10.22322/dkb.v36i1.4777 
IlKh Dinamika Kerajinan dan Batik: Majalah Ilmiah. Vol. 36 No. 1, Juni 2019, Hal. 1- 14 